\title{
PENGARUH PEMBERDAYAAN PEGAWAI TERHADAP EFEKTIVITAS KERJA PADA KANTOR PUSAT PT POS INDONESIA (PERSERO)
}

\author{
Oleh : Mira Veranita \\ Politeknik Piksi Ganesha \\ E-Mail : mirave2198@gmail.com
}

\begin{abstract}
This research is based on the problem of the low work effectiveness at PT Pos Indonesia (persero) which is caused by the empowerment of human resources variable. The methods of this research is descriptive and explanatory survey method, which explains the phenomenon by explaining the influence of human resource empowerment as free variable and is symbolized by $X$ to work effectiveness which symbolized by Y.This research uses quantitative analysis technique through band analysis (path analysis)which its purpose is to know the great influence of human resources empowerment to work effectiveness either simultaneously on partial. The research mentions that only six dimension of human resources empowerment examined in influencing work effectiveness and it got successful results. Envision (X1)influences on job activity as 49.23\%, Educate (X2) influences on job effectivity as-59.07\%, Eliminate (X3) influences on work effectiveness as $14.44 \%$, Express (X4) influences on job activity as $23.40 \%$, Enthuse (X5) influences on work effectiveness as $34.34 \%$, and Expect((X8) influences on work activity as $29.30 \%$. The settlement human resources empowerment variable by simultaneously have an effect on positive in influencing work effectiveness at PT Pos Indonesia (persero). The conclusion of this research indicates that the low work effectiveness at PT Pos Indonesia (persero) can be improved by empowerment of human resources.
\end{abstract}

Keyword :Empowerring; Empowerment; Work Effectiveness

\section{PENDAhuluan}

Era globalisasi dan kompetisi saat ini mengakibatkan terjadinya perubahan-perubahan sosial, inovasi teknologi dan bertambah ketatnya persaingan yang menuntut perusahaan-perusahaan dan industri di Indonesia berkompetisi dan mempersiapkan diri untuk menghadapi tantangan masa depan.

Paradigma bisnis dunia mengalami perubahan, seiring dengan era perdagangan global (AFTA 2003, APEC 2020 dan WTO 2010), yang ditandai dengan berbagai kesepakatan antar negara dunia, yang memungkinkan siapapun masuk dan ikut bermain dalam kegiatan usaha termasuk jasa pos dan pengiriman.

Undang-undang no. 5/1999 tentang larangan monopoli dan persaingan tidak sehat, serta Undang-undang no. 8/1999 tentang perlindungan konsumen mengharuskan PT Pos Indonesia (Persero) memberikan layanan yang prima baik dari sisi produk maupun pelayanan, serta kejujuran dan kepastian kepada pelanggan.

PT Pos Indonesia (Persero) adalah institusi publik yang turut mendukung pembangunan di Indonesia, merupakan salah satu BUMN terbesar dengan jumlah pegawai yang tersebar dalam 11 wilayah usaha di seluruh Indonesia. PT Pos Indonesia (Persero) dewasa ini sedang menghadapi tantangan yang berat dalam bisnisnya sebagai akibat dari kemajuan teknologi informasi dan komunikasi yang secara langsung berakibat terhadap keseluruhan aktivitas bisnisnya.

Aktivitas-aktivitas bisnis PT Pos Indonesia (Persero) yang menerima dampak sangat berat adalah lini bisnis : komunikasi (dengan munculnya berbagai alat komunikasi elektronik seperti telex, facsimile, e-mail, telepon selular dan sebagainya), layanan keuangan ( dengan munculnya teknologi ATM, Credit Caed, dan sebagainya) dan logistik (dengan bermunculannya perusahaan-perusahaan kompetitor yang lebih cepat, aman dan mudah).

Dampak-dampak tersebut menunjukkan bahwa PT Pos Indonesia (Persero) harus melakukan perbaikan-perbaikan terhadap lini bisnisnya, sehingga mampu bersaing secara sehat dalam melayani kebutuhan masyarakat.

Perbaikan yang paling mendasar adalah dari sisi sumber daya manusia, karena manusia merupakan faktor terpenting di dalam pencapaian tujuan organisasi. Tujuan organisasi akan terwujud apabila PT Pos Indonesia (Persero) mampu memberdayakan sumber daya manusia yang PENGARUH PEMBERDAYAAN PEGAWAI TERHADAP EFEKTIVITAS KERJA PADA KANTOR PUSAT PT POS INDONESIA (PERSERO)

Jurnal Bisnis Wirausaha ISSN 1693-234X Volume 7 No.1 Agustus 2012 dimilikinya, sehingga memberi energi secara optimal yang membuatnya mampu meningkatkan efektivitas kerja pegawainya.

Pemberdayaan (empowerment) pada dasarnya mengacu pada usaha menumbuhkan keinginan kepada seseorang dan pemberian peluang serta kesempatan bagi bawahan untuk mengaktualisasikan diri, meningkatkan potensi dan kemampuan yang dimiliki, serta memberikan pengalaman psikologis yang membuat seseorang merasa berdaya. Dalam hal ini Stewart (2006: 22) mengatakan :

Pemberdayaan, sederhananya merupakan cara yang amat praktis dan produktif untuk mendapatkan yang terbaik dari diri kita sendiri dan dari staf kita. Dituntut lebih dari sekedar pendelegasian agar kekuasaan ditempatkan secara tepat sehingga dapat digunakan secara efektif, yakni dekat dengan pelanggan / konsumen. Ini berarti bukan hanya perlu pelimpahan tugas, melainkan juga proses pengambilan keputusan dan tanggungjawab secara penuh.

Berdasarkan pengamatan sementara, efektivitas kerja pegawai di Kantor Pusat PT Pos Indonesia tampak belum optimal. Hal ini diduga diakibatkan kurangnya pemberdayaan sumber daya manusia, padahal manusia (pegawai) merupakan kunci keberhasilan perusahaan. Belum optimalnya efektivitas pegawai ini dapat dilihat dari kurangnya perhatian pegawai terhadap pentingnya ketepatan waktu dalam penyelesaian pekerjaan sehingga menjadikan hasil kerja yang diperolehpun tidak optimal. Padahal efektivitas kerja pegawai merupakan unsur strategis untuk mencapai tujuan sehingga dapat menjadi organisasi yang efektif.

\section{IDENTIFIKASI MASALAH}

1. Berapa besar pengaruh pemberdayaan terhadap efektivitas kerja pegawai Pada Kantor Pusat PT Pos Indonesia (Persero).

2. Berapa besar pengaruh pemberdayaan melalui dimensi-dimensi Mengembangkan Visi Bersama, Mendidik, Menyingkirkan rintangan-rintangan, Mengungkapkan, Menyemangati, Memperlengkapi, Menilai dan Mengharapkan, terhadap efektivitas kerja pegawai Pada Kantor Pusat PT Pos Indonesia (Persero). 


\section{KERANGKA PEMIKIRAN}

\section{A. Pemberdayaan Sumber Daya Manusia}

Pemberdayaan, yang dalam bahasa Inggris dikenal dengan "Empowerment", adalah sebuah konsep yang lahir sebagai bagian dari perkembangan alam pikiran masyarakat dan kebudayaan barat terutama Eropa.

Pemberdayaan dapat digunakan sebagai suatu alat untuk memotivasi para pegawai dalam mencapai efektivitas kerja.

Guna memahami konsep pemberdayaan secara benar, di bawah ini diuraikan beberapa pengertian dan definisi tentang pemberdayaan sumber daya manusia.

Ada beraneka ragam pengertian pemberdayaan, tergantung dari sudut mana para ahli memandangnya. Salah satunya adalah yang diungkapkan oleh Cook dan Steve dalam Sedarmayanti (2003:59), yang mengatakan bahwa :

Empowerment (Pelimpahan wewenang) akan memberikan filosofis praktis serta sarana perubahan untuk membantu memperbaiki, baik terhadap kepuasan pelanggan pelanggan maupun pegawai dan dengan demikian juga dapat membantu dapat memperbaiki keefektivan organisasi. Empowerement merupakan perubahan yang terjadi pada falsafah manajemen yang dapat membantu menciptakan suatu lingkungan dimana setiap individu dapat menggunakan kemampuan dan energinya untuk meraih tujuan organisasi.

Webster, Oxford English Dictionary yang dikemukakan oleh Sedarmayanti (2003:59), kata Empower mengandung dua arti, pengertian pertama adalah to give power or authority to dan pengertian kedua berarti to give ability to or enable. Dalam pengertian pertama diartikan sebagai memberi kekuasaan, mengalihkan kekuatan atau mendelegasikan otorisasi kepada pihak lain, sedangkan dalam pengertian kedua diartikan sebagai upaya untuk memberikan kemampuan atau keberdayaan.

Konsep pemberdayaan ini menampakkan dua kecenderungan. Yang pertama pemberdayaan lebih menekankan pada proses memberikan atau mengalihkan sebagian kekuasaan, kekuatan atau kemampuan (power) kepada masyarakat organisasi atau individu agar lebih berdaya. Sedangkan pengertian yang kedua, menekankan pada proses merangsang, mendorong dan memotivasi individu agar mempunyai kemampuan atau keberdayaan untuk menentukan apa yang menjadi pilihan hidupnya.

Pendapat lain yang sejalan dengan beberapa pendapat di atas adalah yang diungkapkan oleh Jones (2001:84) bahwa : "Empowerment is the process of giving employees throughout an organization the authority to make important decisions and to be responsible for their outcomes". Pemberdayaan memberikan kewenangan kepada pegawai untuk membuat keputusan-keputusan penting dan bertanggung jawab atas akibat keputusan-keputusan yang dibuatnya.

Hope dan Mühlemann (1997:300), "Empowerment is giving employees the power to make decisions as they think appropriate to enable them to serve the customer". Pemberdayaan juga memberikan kekuasaan kepada para pegawai untuk membuat keputusan-keputusan yang mereka pikir memang layak untuk dilakukan sehingga mereka mampu melayani konsumen dengan lebih baik. ,

Pemberdayaan adalah upaya yang mendorong dan memungkinkan para pegawai untuk mengemban tanggung jawab pribadi atas cara mereka dalam melaksanakan tugastugasnya untuk mencapai tujuan-tujuan organisasi.

Pengertian pemberdayaan juga diungkapkan oleh Daft (1998:449) : "Empowerment is power sharing, the delegation of power or authority to subordinates in the organization. It means giving power to other in the organization so they can act more freely to accomplish their jobs ".

Dari berbagai definisi di atas dapat disimpulkan bahwa pemberdayaan sumber daya manusia merupakan pemberian kekuasaan kepada pegawai untuk membuat keputusan dan bertanggung jawab terhadap keputusan yang diambilnya atau dapat dikatakan bahwa pemberdayaan dapat mendorong terjadinya inisiatif dan respons, sehingga seluruh masalah yang dihadapi dapat diselesaikan dengan cepat dan fleksibel. Pegawai dapat dengan bebas memutuskan sesuatu tanpa harus melapor terlebih dahulu atau merasa khawatir akan reaksi dari pimpinan mereka.

Secara konseptual, pemberdayaan merupakan upaya memberikan otonomi, wewenang dan kepercayaan kepada setiap individu dalam suatu organisasi, serta mendorong mereka untuk kreatif agardapat merampungkan tugas sebaikbaiknya. Pegawai diberi keleluasaan untuk mengambil tindakan-tindakan yang dipandang tepat dalam rangka melayani pelanggan, termasuk menangani keluhan mereka.

Melalui pemberdayaan, diharapkan terjadi sharing of power, dimana bawahan dilibatkan secara bersama-sama dengan pihak manajemen untuk melakukan perubahan. Selain itu pemberdayaan sumber daya manusia memiliki beberapa manfaat seperti yang diutarakan oleh Hope dan Mühlemann (1997:331),

The benefits of empowerment include the following :

- Happier customers who are traded as individuals,

- Happier customers who have had a problem resolved quickly,

- A more loyal customers base as consequence of the above,

- Reduce costs in getting new customers,

- Happier employees who feel valued,

- Happier employees who feel able to do a good job,

- More variety and more interesting jobs,

- Increased loyalty to the firm by employees,

- Less absenteeism,

- Lower turnover

- Reduce hiring costs,

- Reduce training of new employees costs,

- Manager with more time to plan as opposed to directing/problem solving for subordinartes.

Secara garis besar, ada beberapa manfaat yang diharapkan dari pemberdayaan sumber daya manusia pada organisasi jasa (Bowen dan lawler III, 1992 dalam Zeithaml dan Bitner, 2003:334) yaitu :

1. Quicker online response to customer needs during service delivery;

2. Quicker online response to dissatisfied customers during serve recovery;

3. Employees feel better about their jobs and themselves ;

4. Employees will interact with customers with more warmth and enthusiasm;

5. Empowered employees are a great source of service ideas ;

6. Great word-of-mouth advertising from customers ;

Pernyataan di atas tentang manfaat-manfaat pemberdayaan terhadap kualitas pelayanan yang diberikan bersifat positif yang berarti bahwa semakin baik atau sering dilakukan pemberdayaan, maka akan semakin tinggi kualitas pelayanan yang dapat diberikan yaitu lebih cepat, dan lebih responsif terhadap kebutuhan pelanggan (masyarakat). Selain itu pegawai yang telah diberdayakanpun alkan lebih percaya diri, lebih senang (enjoy) terhadap pekerjaannya dan lebih 
efisien dalam melakukan pelayanan kepada masyarakat atau pelanggan.

Menurut Robert A.Brymer dalam Clutterbuck \& Kernaghan (2003:201), menggambarkan dua struktur pemberdayaan alternatif yang bisa diterapkan untuk membantu staf yang diberdayakan membuat keputusankeputusan dan membantu manajemen menjaga konsistensi dan kontrol : pemberdayaan terstruktur dan pemberdayaan fleksibel.

\section{Pemberdayaan Terstruktur}

Pemberdayaan terstruktur memberikan panduan-panduan spesifik bagi karyawan lini depan. Ini memberikan mereka kemampuan untuk membuat keputusan-keputusan, tetapi dalam batas-batas yang sudah ditentukan dan dirinci. Panduan-panduan memberitahu staf secara tepat apa yang bisa mereka lakukan untuk memecahkan setiap masalah yang paling umum dihadapi pelanggan.

\section{Pemberdayaan Fleksibel.}

Pemberdayaan fleksibel memberi karyawan keleluasaan lebih besar dalam membuat keputusan-keputusan yang secara langsung mempengaruhi pelayanan pelanggan. Dalam organisasi yang menggunakan pemberdayaan fleksibel, manajemen mengeluarkan panduanpanduan dan batas-batas yang luas dan karyawan diharapkan dan dilatih untuk menggunakan nalar bisnis yang baik dalam memilih alur tindakan terbaik dalam memuaskan pelanggan.

Dalam pemberdayaan fleksibel, karyawan harus menanyai pelanggan : 'apa yang bisa saya lakukan untuk memecahkan masalah ini?' dan diberi wewenang untuk mengambil langkahlangkah yang perlu untuk memuaskan si pelanggan. Karyawan diharapkan berkonsultasi dengan supervisor hanya dalam situasi-situasi yang ekstrim (misalnya,jika seorang tamu bersikeras bahwa rekeningnya yang mencapai $\$ 500$ itu harus dihapuskan semuanya karena bantal-bantal di hotel itu tidak nyaman). Jika tidak, karyawan mempunyai wewenang untuk membuat keputusan-keputusan yang masuk akal untuk memuaskan pelanggan.

Dengan pemberdayaan fleksibel, otonomi dan kekuasaan yang diberikan kepada karyawan yang diberdayakan jauh melebihi wewenang untuk membuat untuk membuat penyesuaianpenyesuaian yang menyangkut transaksi keuangan. Inti gagasan itu justru untuk mendorong agar karyawan meningkatkan pelayanan pelanggan ke sebanyak mungkin arah" (A Brymer dalam Clutterbuck \& Kernaghan (2003:203)

Dengan pemberdayaan terstruktur maupun fleksibel, tiga faktor tambahan harus diperhatikan jika pemberdayaan diharapkan berhasil dalam organisasi jasa :

(A Brymer dalam Clutterbuck \& Kernaghan (2003:201),

(a) para manajer harus memastikan agar staf mendapatkan informasi yang mereka butuhkan, (b) para manajer harus memastikan agar ada orang yang menangani masalah pelayanan pelanggan yang muncul dan (c) para manajer harus memberi karyawan kebebasan untuk membuat kesalahankesalahan.

DeVrye (1994:159) menjelaskan Seven Key of Empowerment, terdiri dari langkah-langkah :

1. Eliminate unnecessary bureaucracy to make employees more responsible and respon-able;

2. Look at reactive ways to say "yes" to customer problems, rather than simple justification to say "no";

3. Encourage sensible risk-taking and learning from mistakes

4. Support employees and catch people doing things right.

5. Recognize and reward employees for a job well done. Say "thank you" more often,

6. Make everyone feel an important part of the overall customer team, whether serving internal or external customers ;

7. In my own organization, I will improve service through empowerment;

Pemberdayaan mampu mengurangi hambatanhambatan birokrasi yang tidak perlu sehingga membuat pegawai memiliki tanggung jawab dan daya tanggap yang tinggi terhadap permasalahan yang dihadapi. Pemberdayaan juga akan membiasakan pegawai menanggapi setiap permasalah yang ditemui, terutama yang berkaitan dengan pelayanan, karena pegawai memiliki keberanian untuk mengambil resiko dan belajar dari kesalahan. Pemberdayaan memberikan manfaat yang tidak sedikit kepada pegawai, karena akan memberikan dukungan kepada pegawai untuk melakukan pekerjaan dengan benar, memperkenalkan teknik bekerja yang baik, sehingga tercipta kondisi kerja yang lebih menyenangkan yang memungkinkan pelayanan diberikan dengan maksimal.

Pemberdayaan sumber daya manusia memerlukan waktu yang tidak sedikit tetapi akan mengalir ke seluruh organisasi dan menyebabkan perubahan di seluruh bagian organisasi. Permulaan untuk melakukan proses pemberdayaan, harus didasarkan pada penilaian jujur tentang budaya dalam organisasi pada saat terakhir. Penilaian tersebut akan mengarah kepada suatu kesadaran yang lebih mendalam tentang apa yang perlu diubah,mengapa perlu diubah dan apa hambatan utamanya.

Faktor-faktor penting atau dimensi-dimensi yang menjadi bagian dari Pemberdayaan Sumber Daya Manusia menurut Stewart (2006:112) adalah :

1.envision (mengembangkan visi bersama);

2.educate (mendidik);

3.eliminate (menyingkirkan rintangan-rintangan);

4.express (mengungkapkan);

5.enthuse (menyemangati);

6.equip (memperlengkapi);

7.evaluate (menilai);

8.expect (mengharapkan);

\section{B. Efektivitas Kerja}

Konsep efektivitas merupakan konsep yang luas mencakup berbagai faktor dan dari sudut pandang mana kita melihatnya. Pada umumnya efektivitas dihubungkan dengan berbagai cara pencapaian tujuan baik dari segi proses ataupun dari segi waktu. Bagi beberapa organisasi pencapaian hasil 
berupa laba merupakan salah satu indikator keberhasilan pencapaian efektivitas, namun Steers (1985:1) menyatakan bahwa "Sulit membayangkan adanya organisasi yang dapat bertahan lama jika yang dikejar semata-mata hanya laba dan sama sekali mengabaikan kebutuhan serta tujuan para karyawan".

Kebutuhan dan tujuan pegawai di dalam organisasi menjadi sedemikian penting untuk menjadi perhatian para pimpinan karena faktor manusia mempunyai peranan yang besar dalam pencapaian tujuan organisasi. Agar lebih jelasnya dapat dikemukakan beberapa pendapat para ahli yang akan diuraikan di bawah ini.

Westra (1985:149) merumuskan pengertian efektivitas sebagai berikut : "Efektivitas adalah : suatu keadaan yang mengandung pengertian terjadinya sesuatu efek atau akibat yang dikehendaki. Kalau seseorang melakukan suatu perbuatan dengan maksud tertentu yang memang dikehendaki, maka orang itu dikatakan efektif kalau menimbulkan akibat sebagaimana yang dikehendakinya."

Sedangkan Stoner (1996:9) menyampaikan : " Efektivitas itu ialah kemampuan untuk menentukan tujuan yang memadai : 'melakukan hal yang tepat'”. Jadi, menurutnya, sesuatu pekerjaan dikatakan efektif apabila suatu pekerjaan dilakukan sesuai dengan aturan dan prosedur yang berlaku dan sesuai dengan rencana yang telah dibuat. Pendapat Stoner ini senada dengan yang disampaikan oleh Emerson dalam Handayaningrat (1996:16) menjelaskan arti kata efektivitas (effectiveness) sebagai "Effectiveness is a measuring in term of attaining prescribed goals or objective".

Pada umumnya para ahli menunjuk efektivitas pada pencapaian tujuan, namun Steers (1985:5) memberikan batasan yang cukup sederhana dalam merumuskan pencapaian tujuan tersebut, yaitu : Kelebihan utama dari ancangan tujuan dalam menilai efektivitas adalah bahwa sukses organisasi diukur menurut maksud organisasi dan menurut pertimbangan nilai si penyelidik (yaitu, apa yang "seharusnya" dilakukan menurut orang itu).

Mengukur efektivitas organisasi tidak lepas dari efektivitas kerja dari anggota-anggota di dalam organisasi sebagai pelaksana misi, fungsi dan tugas-tugas organisasi berdasarkan peran yang diberikan kepada mereka.

Efektivitas kerja menunjuk kepada kombinasi antara proses fisik dan mental manusia dalam pencapaian tujuan organisasi. Dalam kondisi yang ideal tujuan organisasi dan tujuan perorangan adalah harus sejalan. Indrawijaya (2000:214) menyebutkan "Efektivitas organisasi pada dasarnya adalah efektivitas perseorangan". Namun Steers (1985:211) mengatakan :

.... para anggota organisasi mungkin merupakan faktor pengaruh yang paling penting atas efektivitas karena perilaku merekalah yang dalam jangka panjang akan memperlancar atau merintangi tercapainya tujuan organisasi .

Tujuan utama dari penataan aktivitas manajemen adalah upaya untuk pencapaian tujuan perusahaan dengan menggunakan seluruh sumber daya yang dimiliki secara efektif dan efisien. Pengertian efektivitas dalam suatu organisasi mempunyai arti yang berbeda-beda, tergantung dari kerangka acuan yang dipakainya. Hal ini disebabkan keanekaragaman sifat dan komposisi dari efektivitas suatu organisasi.

Steers (1985:35) mengatakan : Pengertian efektivitas kerja adalah sebagai suatu keadaan yang menunjukkan tingkat keberhasilan manajemen dalam mencapai tujuan yang telah ditetapkan terlebih dahulu. Berdasarkan pengertian tersebut, efektivitas kerja merupakan suatu keberhasilan organisasi yang dijalankan oleh pimpinan dalam menyelesaikan pekerjaan sesuai dengan tujuan yang telah ditetapkan. Selain itu efektivitas kerja merupakan suatu pengukuran, dalam arti sejauhmana organisasi melaksanakan tugas sesuai sasarannya dengan melihat jumlah kualitas dari jasa yang telah dihasilkan berdasarkan target yang telah ditentukan.

Ada pandangan-pandangan lain mengenai efektivitas, antara lain yang diungkapkan oleh Gibson (1996:25) yaitu :

1. Efektivitas individu yang menekankan pada : (a) Hasil karya pegawai atau anggota tertentu dari organisasi; (b) Prestasi kerja individu dinilai secara rutin lewat proses evaluasi hasil karya yang merupakan dasar bagi kenaikan gaji, promosi dan imbalan lain yang tersedia dalam organisasi.

2. Efektivitas kelompok yang menekankan pada : (a) Bekerja secara bersama-sama dalam kelompok ; (b) Hasil yang dicapai jumlah kontribusi dari semua anggotanya.

3. Efektivitas organisasi, terdiri dari individu dan kelompok, yang menekankan pada hasil karya yang lebih tinggi tingkatnya dari daripada jumlah hasil karya tiap-tiap bagiannya.

Hubungan ketiga pandangan mengenai efektivitas itu diperlihatkan pada gambar berikut ini :

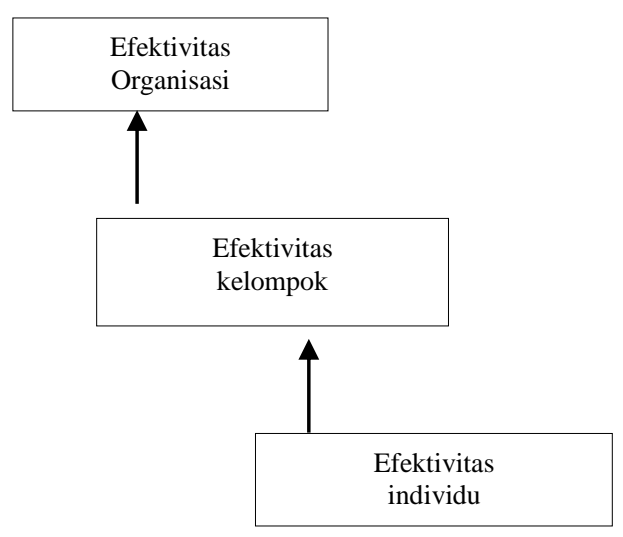

Gambar 1

Tiga Pandangan Mengenai Efektivitas Organisasi Sumber : David J Lawless dalam Gibson et.el (1996)

Anak panah yang menghubungkan tiap-tiap tingkat tidak menunjukkan bentuk khusus dari hubungan tersebut, karena efektivitas individu tidaklah harus merupakan sebab dari efektivitas kelompok, begitupula bahwa efektivitas kelompok adalah jumlah dari efektivitas individu.

Efektivitas kerja menurut Siagian (1997:151) adalah :

Penyelesaian pekerjaan tepat waktu yang telah ditetapkan sebelumnya, artinya apakah pelaksanaan suatu tugas dinilai baik atau tidak sangat tergantung bilamana tugas tersebut diselesaikan dan terutama bagaimana cara melaksanakannya dan berapa biaya yang diselesaikan untuk itu.

Efektivitas seseorang dapat dilihat dari hasil kegiatan, jumlah yang dicapai dan juga kemampuan beradaptasi dengan perubahan lingkungan organisasi baik internal maupun eksternal. Pada organisasi pemerintah, 
pekerjaan yang dilakukan sekalipun tidak efisien dalam arti input dan output, tetapi bila tujuan organisasi tercapai maka hal tersebut dapat dikatakan efektif sebab mempunyai pengaruh yang sangat besar terhadap kepentingan masyarakat di berbagai bidang.

Penyelesaian pekerjaan tepat pada waktunya merupakan suatu hal yang penting, sebab tujuan suatu organisasi tidak akan tercapai bila tidak ditunjang oleh pelaksanaan pekerjaan yang efektif. Steers (1985:45) menyatakan efektivitas kerja dapat dilihat dari tiga aspek utama yaitu "(1) Ketepatan kualitas; (2) Ketepatan kuantitas, (3) Ketepatan waktu"

\section{Keterkaitan Pemberdayaan dengan Efektivitas Kerja Pegawai.}

Pemberdayaan sumber daya manusia adalah suatu strategi yang digunakan oleh organisasi untuk meningkatkan motivasi dan efektivitas kerja pegawai dan merupakan upaya untuk mengoptimalkan eksistensi pegawai sehingga mampu berperan dalam melakukan aktifitas yang didukung oleh kompetensi dan profesionalisme dalam memberikan pelayanan yang dapat meningkatkan efektivitas kerja pegawai secara optimal.

Seperti dikemukakan oleh Stewart (2006:31) : Pemberdayaan juga memberikan manfaat-manfaat besar bagi organisasi. Salah satu manfaat adalah bertambahnya efektivitas organisasi. Pemberdayaan mendatangkan manfaat itu dengan meniadakan halangan dan hambatan kerja yang diakibatkan oleh pengendalian ketat akibat pendekatan manajemen tradisional.

Pemberdayaan sumber daya manusia yang mampu menumbuhkan profesionalisme dan kemampuan kerja yang tinggi akan membuat organisasi memiliki akuntabilitas yang tinggi, kinerja yang tinggi, komunikasi terbuka, kinerja yang tinggi dan efektivitas kerja yang tinggi pula.

Rust, Anthony dan Timothy (1996 : 392) menjelaskan bahwa Pemberdayaan merupakan program meningkatkan perilaku pegawai dengan mendorong pegawai ikut serta dalam pengambilan keputusan dan terutama melibatkan pegawai lini depan, sayangnya keterlibatan pegawai dalam memecahkan masalah ini sangat terbatas.

Padahal menurut Gavares (1993 : i) ada lima aspek yang mempengaruhi keterlibatan anggota pada pemberdayaan, yaitu kontekstual, organisasi, manajerial, personil dan interpersonal.

Hasil dari sebuah proses pemberdayaan diharapkan akan menghasilkan pegawai yang berkualitas yang memiliki efektivitas kerja yang tinggi. Selain memberikan manfaat bagi organisasi, pemberdayaan juga akan meningkatkan efektivitas kerja pegawai, sebagaimana diungkapkan oleh Rokhman dalam Soetjipto (2003:132) : "Melalui program pemberdayaan, organisasi berusaha memacu kreatifitas dan daya inovatif yang dimiliki karyawan dengan pemberian wewenang dan tanggung jawab pada bawahan untuk mengambil keputusan, sehingga turut meningkatkan efektivitas kerja karyawan"

\section{METODE PENELITIAN}

Metode yang digunakan dalam penelitian ini adalah metode survei melalui pendekatan deskriptif analisis, sebagaimana menurut Nazir (1985:63) :

Variabel penelitian terdiri dari variabel bebas yaitu Pemberdayaan Sumber Daya Manusia, selanjutnya dilambangkan dengan $(X)$ dan variabel terikat yaitu Efektivitas Kerja Pegawai, selanjutnya dilambangkan dengan (Y). Variabel bebas (X) yaitu Pemberdayaan Sumber Daya manusia dibagi menjadi 8 sub variabel sesuai dengan dimensinya yaitu (X1) Mengembangkan Visi Berassama,
(X2) Mendidik, (X3) Menyingkirkan rintangan-rintangan, (X4) Mengungkapkan, (X5) Menyemangati, (X6) Memperlengkapi, (X7) Menilai, dan (X8) Mengharapkan.

Teknik pengumpulan data yang digunakan dalam pelaksanaan penelitian ini terdiri dari : Studi kepustakaan, Studi lapangan, Observasi, Wawancara dan Angket, yaitu teknik pengumpulan data melalui daftar pertanyaan yang diberikan kepada para pegawai pada Kantor Pusat PT Pos Indonesia (Persero).

Teknik pengolahan data yang digunakan adalah teknik analisis kuantitatif untuk menganalisis dan mengolah hasil penelitian. Untuk menganalisis data yang terkumpul digunakan pendekatan statistik, dengan menggunakan analisis deskriptif dan analisis jalur (path analysis).

Analisis data yang digunakan adalah analisis statistik dengan model analisis jalur (path analysis) untuk mengungkapkan antara variabel dan interpretasinya. Data yang terkumpul dari hasil kuesioner yang telah dikembalikan merupakan data mentah. Data yang dianggap memenuhi syarat adalah data yang hanya memiliki satu jawaban untuk setiap pernyataan. Data hasil pengisian kuesioner yang memenuhi persyaratan dikumpulkan dan diolah dengan menggunakan bantuan Software SPSS versi 11 .

Hipotesis konseptual diterjemahkan ke dalam diagram gambar di bawah ini : 


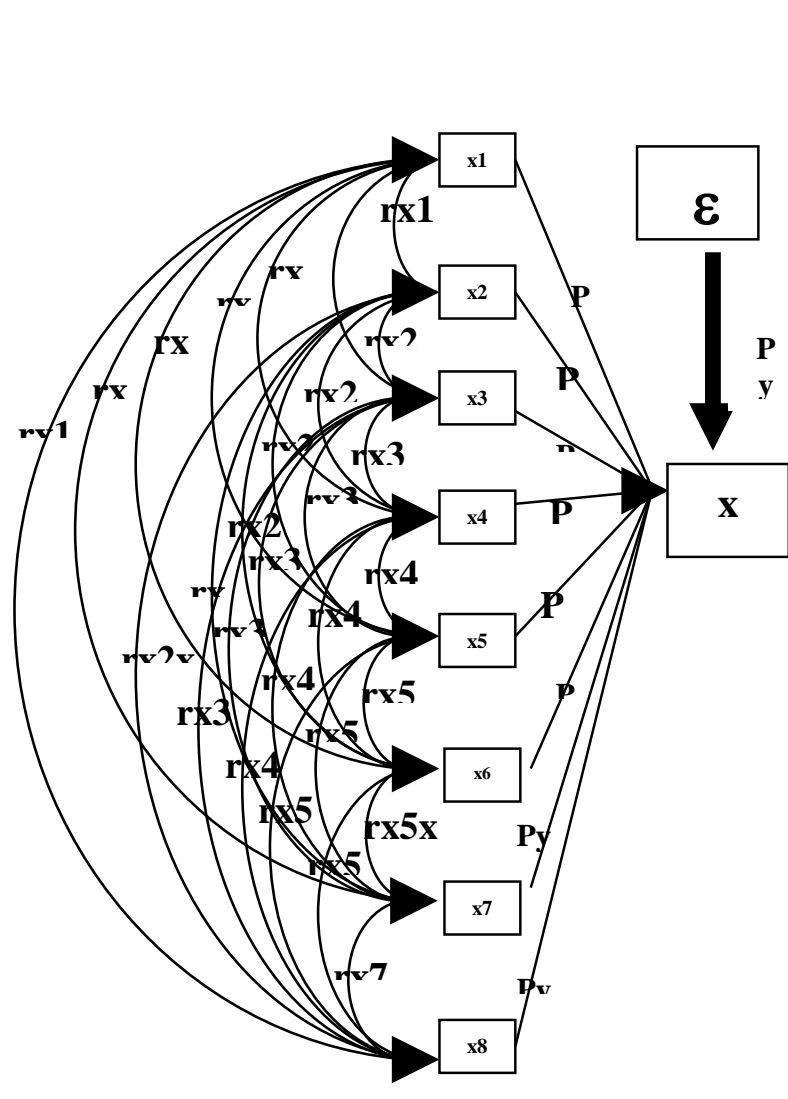

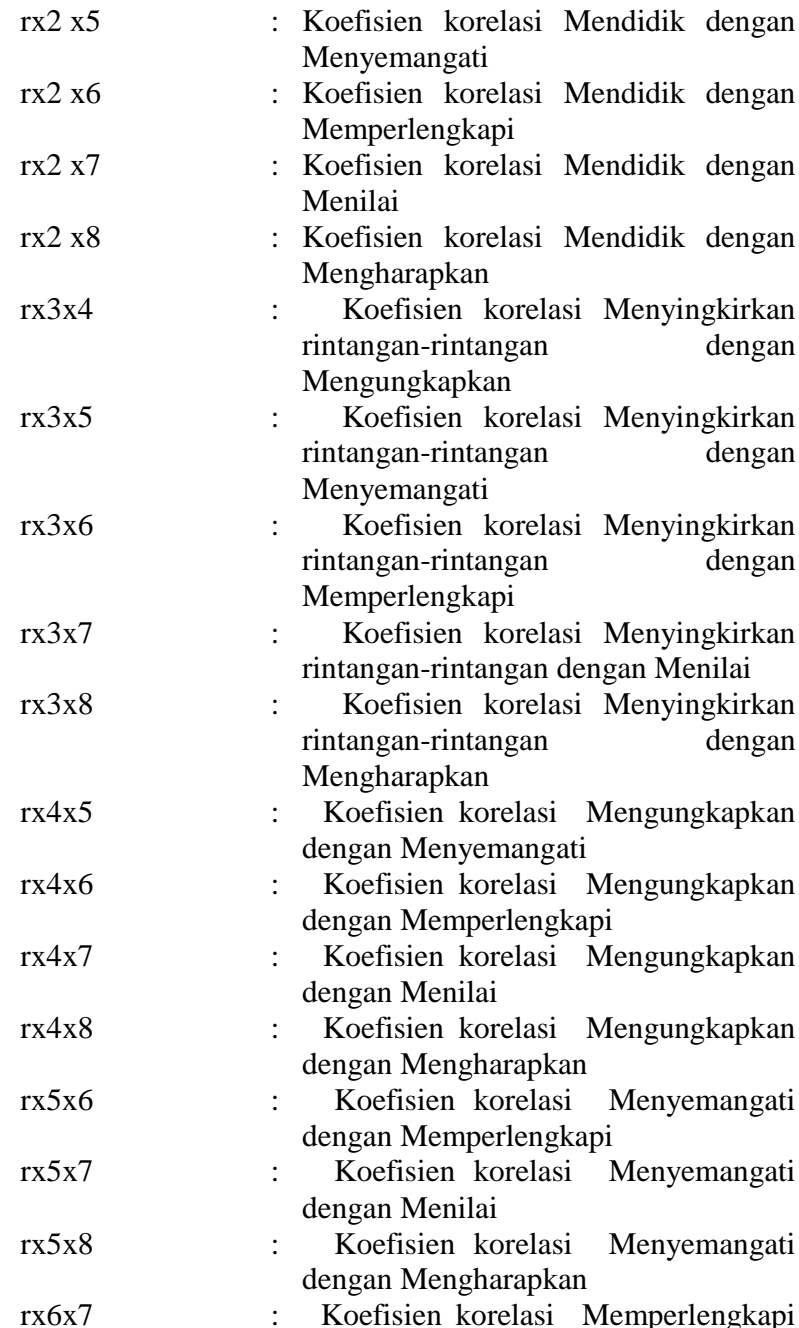

Gambar 2

Struktur Penelitian Pengaruh Variab X terhadap Y Keterangan :

\begin{tabular}{|c|c|}
\hline $\mathrm{x} 1$ & : Mengembangkan visi bersama \\
\hline $\mathrm{x} 2$ & : Mendidik \\
\hline $\mathrm{x} 3$ & : Menyingkirkan rintangan-rintangan \\
\hline $\mathrm{x} 4$ & : Mengungkapkan \\
\hline $\mathrm{x} 5$ & : Menyemangati \\
\hline $\mathrm{x} 6$ & : Memperlengkapi \\
\hline $\mathrm{x} 7$ & : Menilai \\
\hline $\mathrm{x} 8$ & : Mengharapkan \\
\hline $\mathrm{rx} 1 \times 2$ & $\begin{array}{l}\text { Koefisien korelasi } \\
\text { visi bersama dengan } \\
\text { Mendidik }\end{array}$ \\
\hline $\mathrm{rx} 1 \times 3$ & $\begin{array}{l}\text { Koefisien korelasi Mengembangkan } \\
\text { visi bersama dengan Menyingkirkan } \\
\text { rintangan-rintangan }\end{array}$ \\
\hline $\mathrm{rx} 1 \times 4$ & $\begin{array}{l}\text { Koefisien korelasi Mengembangkan } \\
\text { visi bersama dengan Mengungkapkan }\end{array}$ \\
\hline $\mathrm{rx} 1 \times 5$ & $\begin{array}{l}\text { : Koefisien korelasi Mengembangkan } \\
\text { visi bersama dengan Menyemangati }\end{array}$ \\
\hline $\mathrm{rx} 1 \mathrm{x} 6$ & $\begin{array}{l}\text { : Koefisien korelasi Mengembangkan } \\
\text { visi bersama dengan Memperlengkapi }\end{array}$ \\
\hline $\mathrm{rx} 1 \times 7$ & $\begin{array}{l}\text { : Koefisien korelasi Mengembangkan } \\
\text { visi bersama dengan Menilai }\end{array}$ \\
\hline $\mathrm{rx} 1 \mathrm{x} 8$ & $\begin{array}{l}\text { : Koefisien korelasi Mengembangkan } \\
\text { visi bersama dengan Mengharapkan }\end{array}$ \\
\hline $\mathrm{rx} 2 \times 3$ & $\begin{array}{l}\text { Koefisien korelasi Mendidik dengan } \\
\text { Menyingkirkan rintangan-rintangan }\end{array}$ \\
\hline $\mathrm{rx} 2 \times 4$ & $\begin{array}{l}\text { Koefisien korelasi Mendidik dengan } \\
\text { Mengungkapkan }\end{array}$ \\
\hline
\end{tabular}

rx6x8

$\mathrm{rx} 7 \mathrm{x} 8$

$\mathrm{y}$

Pyx1

Pyx2

Koefisien korelasi Memperlengkapi
dengan Menilai

Koefisien korelasi Memperlengkapi dengan Mengharapkan

Koefisien korelasi Menilai dengan Mengharapkan

Efektivitas Kerja Pegawai

Koefisien jalur yang menunjukkan besarnya pengaruh Mengembangkan Visi Bersama dengan Efektivitas Kerja Pegawai

Koefisien jalur yang menunjukkan besarnya pengaruh Mendidik dengan Efektivitas Kerja Pegawai

Pyx3

Koefisien jalur yang menunjukkan besarnya pengaruh Menyingkirkan rintangan-rintangan dengan Efektivitas Kerja Pegawai

Pyx4

Pyx5

Koefisien jalur yang menunjukkan besarnya pengaruh Mengungkapkan dengan Efektivitas Kerja Pegawai

: Koefisien jalur yang menunjukkan besarnya pengaruh Menyemangati dengan Efektivitas Kerja Pegawai

Pyx6

: Koefisien jalur yang menunjukkan besarnya pengaruh Memperlengkapi dengan Efektivitas Kerja Pegawai

Pyx7 : Koefisien jalur yang menunjukkan besarnya pengaruh Menilai dengan Efektivitas Kerja Pegawai 
Pyx8

Py $\varepsilon$

$\varepsilon$

(empat) komponen :
- Semua variabel yang mempengaruhi y (diluar $\mathrm{x}$ ) yang sudah diidentifikasi

- Semua variabel yang mempengaruhi y (diluar $\mathrm{x}$ ) yang belum diidentifikasi

- Kekeliruan pengukuran

- Komponen yang sifatnya tidak bisa diramalkan

\section{HASIL PENELITIAN}

\section{A. Variabel Pemberdayaan SDM}

Sebagaimana ditunjukkan dalam lampiran-4 hasil olahan data dengan SPSS diperoleh tingkat reliabilitas setiap variabel bebas (Pemberdayaan SDM) sebagai berikut :

No. Dimensi Variabel Nilai Reliabilitas Ukuran

\begin{tabular}{|c|c|c|c|c|}
\hline (a). & $\begin{array}{l}\text { Mengembangan Visi } \\
\text { Sedang }\end{array}$ & Alpha $_{1}$ & $=$ & 0.4551 \\
\hline (b). & $\begin{array}{l}\text { Mendidik SDM } \\
\text { Tinggi }\end{array}$ & $\mathrm{Alpha}_{2}$ & $=$ & 0.7436 \\
\hline (c). & $\begin{array}{l}\text { Menyingkirkan Rintangan } \\
\text { Sedang }\end{array}$ & $\mathrm{Alpha}_{3}$ & $=$ & 0.5920 \\
\hline (d). & $\begin{array}{l}\text { Mengungkapkan Sikap } \\
\text { Sedang }\end{array}$ & Alpha4 & $=$ & 0.5338 \\
\hline (e). & $\begin{array}{l}\text { Menyemangati } \\
\text { Cukup }\end{array}$ & Alpha5 & $=$ & 0.6288 \\
\hline (f). & $\begin{array}{l}\text { Memperlengkapi } \\
\text { Sedang }\end{array}$ & Alpha6 & $=$ & 0.4482 \\
\hline (g). & $\begin{array}{l}\text { Menilai Kerja Pegawai } \\
\text { Cukup }\end{array}$ & Alpha7 & $=$ & 0.6519 \\
\hline (h). & $\begin{array}{l}\text { Mengharapkan Perbaikan } \\
\text { Tinggi }\end{array}$ & Alpha8 & $=$ & 0.7818 \\
\hline
\end{tabular}

Secara keseluruhan, reliabilitas variabel-X, cukup tinggi yakni 80,39\% (Tabel 1)

Tabel 1

Hasil Perhitungan Uji Reliabilitas Variabel X

Reliability Semua Item Variabel X Yang Valid

R E L I A B I L I T Y A N A L Y S I S - S C A L E (ALPHA)

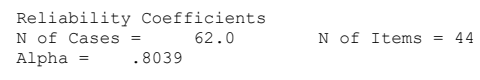

\section{B. Variabel Efektivitas Kerja}

Sebagaimana ditunjukkan dalam lampiran-4 hasil olahan data dengan SPSS diperoleh tingkat reliabilitas setiap variabel terikat (Efektivitas Kerja) sebagai berikut :

No. Dimensi Variabel Nilai Reliabilitas Ukuran

$\begin{array}{llll}\text { (a). } & \text { Ketepatan Kualitas } & \text { Alpha }= & .4231 \\ & \text { Sedang } & \\ \text { (b). } & \text { Ketepatan Kuantitas } & \text { Alpha }= & .4870 \\ \text { (c). } & \begin{array}{l}\text { Sedang } \\ \text { Ketepatan Waktu } \\ \text { Rendah }\end{array} & \text { Alpha }= & .0999 \\ & & \end{array}$

Secara keseluruhan, reliabilitas variabel-Y cukup tinggi, yakni $80,64 \%$ (Tabel 2)

Tabel 2

Hasil Perhitungan Uji Reliabilitas Variabel Y
Reliability Semua Item Variabel X Yang Valid

R E L I A B I L I T Y A N A L Y S I S - S C A L E (ALPHA)

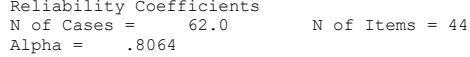

\section{Deskripsi Variabel Pemberdayaan Sumber Daya}

Manusia

Pada bagian ini disajikan penilaian responden terhadap Pemberdayaan Sumber Daya Manusia di Kantor Pusat PT Pos Indonesia (Persero). Berdasarkan operasionalisasi variabel Pemberdayaan Sumber Daya Manusia terdiri dari 8 dimensi, yaitu : Mengembangkan visi bersama, Mendidik, Menyingkirkan rintangan-rintangan, Mengungkapkan, Menyemangati, Memperlengkapi, Menilai dan Mengharapkan.

\section{Analisis Jalur Model Hubungan Antar Variabel Penelitian}

Model hubungan kausal pemberdayaan sumber daya manusia (X), menggunakan 8 dimensi variabel, yakni (X1) Mengembangkan visi bersama, (X2) mendidik, (X3) Menyingkirkan rintang-rintangan, (X4) Mengungkapkan, (X5) Menyemangati, (X6) Memperlengkapi, (X7) Menilai, dan (X8) Mengharapkan terhadap tingkat Efektivitas Kerja (Y), dinyatakan dalam gambar 1 yang merupakan model struktural hubungan antara beberapa variabel $\mathrm{X}$ dengan variabel Y.

Berdasarkan hasil pengolahan data (Analisis Varian /Anova) melalui program SPSS 10.5 dari model struktural yang digunakan (Gambar 4.1), maka langkah analisis data dikerjakan sebagai berikut :

\section{(1). Taksiran Koefisien Model}

Koefisien yang ditaksir dari model analisi jalur antar variabel diatas, terdiri atas taksiran koefisien jalur (Path Coeficient), yang dilambangkan dengan $\rho_{y x i}(i=1,2,3, \ldots, 8)$, dan koefisien korelasional antar variabel bebas $\left(\mathrm{X}_{\mathrm{i}}\right.$ dan $\left.\mathrm{X}_{\mathrm{j}}\right)$, yakni : $\mathrm{r}_{\mathrm{xi} . x \mathrm{j}}$. Analisis ini dilakukan dengan menggunakan skala data interval.

\section{Tabel 3}

Taksiran Koefisien Jalur melalui pendekatan Analisis regresi 


\begin{tabular}{|c|c|c|c|c|}
\hline $\begin{array}{l}\text { Variabel } \\
\text { Bebas } \\
\text { Model } \\
\text { Struktural }\end{array}$ & $\begin{array}{c}\text { Koefisien Jalur } \\
{\left[\rho_{y . x i}\right]}\end{array}$ & $\begin{array}{c}\text { Statistik } \\
\text { Uji i }\end{array}$ & $\begin{array}{c}\text { Nilai } \\
\text { Signifika } \\
\text { nsi } \\
\text { (p-value) }\end{array}$ & $\begin{array}{c}\text { Keputusan } \\
\text { Uji dengan } \\
(\alpha=10 \%)\end{array}$ \\
\hline$X_{1}$ & $\rho_{y . x 1}=0.178$ & 2.045 & 0.046 & Signifikans \\
\hline $\mathrm{X}_{2}$ & $\rho_{y \times x 2}=-0.214$ & -1.921 & 0.060 & Signifikans \\
\hline $\mathrm{X}_{3}$ & $\rho_{y \times 3}=0.204$ & 1.963 & 0.055 & Signifikans \\
\hline $\mathrm{X}_{4}$ & $\rho_{y \times 4}=0.271$ & 2.667 & 0.010 & Signifikans \\
\hline $\mathrm{X}_{5}$ & $\rho_{y \times x}=0.331$ & 2.562 & 0.013 & Signifikans \\
\hline$X_{6}$ & $\rho_{y, x 6}=0.020$ & 0.255 & 0.800 & Non-Signifikans \\
\hline $\mathrm{X}_{7}$ & $\rho_{y, x}=0.040$ & 0.415 & 0.679 & Non-Signifikans \\
\hline $\mathrm{X}_{8}$ & $\rho_{y \times x}=0.211$ & 1.625 & 0.110 & Non-Signifikans \\
\hline
\end{tabular}

3). Taksiran Koefisien Korelasi Antar Variabel Bebas (Eksogen)

Langkah selanjutnya, melakukan perhitungan koefisien korelasi Pearson antar variable eksogenus (Variabel Bebas) ; yakni korelasi antar variabel $\mathrm{X}_{\mathrm{i}}(\mathrm{i}=1,2,3,4,5,8)$, yang hasilnya sebagai berikut :

Tabel 5

Koefisien Korelasi Pearson Antar Variabel Bebas (X)

Tabel diatas, selain menyatakan taksiran nilai koefisien jalur variable bebas $\mathrm{X}_{\mathrm{i}}$ terhadap variable tak bebas Y (kolom-2), juga secara langsung melakukan pengujian signifikansi koefisien jalur variable bebas ke-i $(i=1,2, \ldots, 8)$ dengan variable tak bebas, melalui statistik uji-t (kolom-3). Statistik uji-t tersebut digunakan untuk menguji hipotesis parsial masing-masing koefisien jalur, dalam bentuk berikut :

\section{(2). Pengujian Hipotesis Secara Parsial}

Hipotesis $\rightarrow H_{0}: \rho_{y . x i}=0 \quad$ melawan $H_{1}: \rho_{y x i} \neq 0 \quad(i=1,2,3 \ldots 8)$

Pengujian sifatnya dua arah, sebab proposisi hipotek tidak mengisyaratkan apakah pengaruh $x_{1}$ terhadap y itu merupakan pengaruh yang positif atau negatif.

Statistik Uji : digunakan untuk pengujian parsial yaitu Uji t.-student Besarnya nilai thitung menggunakan rumusan berikut :

$$
t=\frac{y x_{1}}{\sqrt{\frac{\left(1-R^{2} y x_{1} x_{2}\right) C_{n}}{(n-k-1)}}}
$$

Dengan bantuan program SPSS, masing-masing statistik ujinya dinyatakan pada kolom-3, pada tabel 4.25 diatas. Terlihat bahwa, secara statistik uji-t, dengan menggunakan taraf uji ( $\alpha=10 \%$ ), tampak pada kolom-4, peluang koefisien jalur akan signifikans. Jika dibandingkan nilai-nilai peluang ini (p-value), terhadap besar taraf uji yang ditetapkan $(\alpha=10 \%$ atau 0.10$)$, maka hanya 5 -variabel yang signifikans, yaitu (X1) Mengembangkan visi bersama, (X2) mendidik SDM, (X3) Menyingkirkan rintang-rintangan, (X4) Mengungkapkan sikap, dan (X5) Menyemangati kerja. Dengan demikian, model structural sebagaimana dinyatakan dalam gambar 4.1 diatas, perlu direvisi, jika penelitian ini mengandalkan hasil pengujian secara statistik. Sehingga model structural yang baru, hanya melibatkan variable bebas (eksogenus) yang signifikans secara statistik uji. Untuk memastikan variabel bebas mana saja yang akan dilibatkan dalam mengukur pengaruhnya pada variabel terikat ( $\mathrm{Y}=$ efektivitas kerja), digunakan langkah stepwise (Uji Bertahap signifikansi variabel bebas (X), yang secara program SPSS dihasilkan sebagaimana disajikan dalam lampir

Dengan mengandalkan model structural hasil pengujian statistik maka taksiran koefisien jalar (Path Coeficient) yang signifikans saja, diperoleh sebagaimana ditunjukkan dalam table 4.26 berikut

Tabel 4

Taksiran Koefisien Jalur Untuk

variabel bebas Yang Terseleksi (Signifikans)

\begin{tabular}{|c|c|c|c|c|}
\hline $\begin{array}{c}\text { Variabel } \\
\text { Bebas Model } \\
\text { Struktural }\end{array}$ & $\begin{array}{c}\text { Koefisien } \\
\text { Jalur } \\
{\left[\rho_{y . x i}\right]}\end{array}$ & $\begin{array}{c}\text { Stat } \\
\text { Uji t }\end{array}$ & $\begin{array}{c}\text { Nilai } \\
\text { Signifika } \\
\text { nsi } \\
\text { (p-value })\end{array}$ & $\begin{array}{c}\text { Keputusan } \\
\text { Uji dengan } \\
(\alpha=10 \%)\end{array}$ \\
\hline $\mathbf{X}_{1}$ & $\rho_{y . x 1}=\mathbf{0 . 1 7 8}$ & $\mathbf{2 . 1 3 4}$ & $\mathbf{0 . 0 3 7}$ & Signifikans \\
\hline $\mathbf{X}_{2}$ & $\rho_{y . x 2}=\mathbf{- 0 . 2 1 9}$ & $\mathbf{- 2 . 0 1 9}$ & $\mathbf{0 . 0 4 8}$ & Signifikans \\
\hline $\mathbf{X}_{3}$ & $\rho_{y . x 3}=\mathbf{0 . 2 1 3}$ & $\mathbf{2 . 1 2 6}$ & $\mathbf{0 . 0 3 8}$ & Signifikans \\
\hline $\mathbf{X}_{4}$ & $\rho_{y . x 4}=\mathbf{0 . 2 9 8}$ & $\mathbf{3 . 3 2 7}$ & $\mathbf{0 . 0 0 2}$ & Signifikans \\
\hline $\mathbf{X}_{5}$ & $\rho_{y . x}=\mathbf{0 . 3 4 7}$ & $\mathbf{2 . 9 1 8}$ & $\mathbf{0 . 0 0 5}$ & Signifikans \\
\hline $\mathbf{X}_{8}$ & $\rho_{y . x 8}=\mathbf{0 . 2 1 3}$ & $\mathbf{1 . 7 4 9}$ & $\mathbf{0 . 0 8 6}$ & Signifikans \\
\hline
\end{tabular}

Tabel diatas, menyatakan taksiran nilai koefisien jalur yang baru dari variable bebas yang terseleksi (signifikan), yaitu $\mathrm{X}_{1}, \mathrm{X}_{2}, \mathrm{X}_{3}$, $\mathrm{X}_{4}, \mathrm{X}_{5}$ dan $\mathrm{X}_{8}$ terhadap variable terikat $\mathrm{Y}$ (kolom-2), yang signifikans pada keyakinan 90 persen (Taraf Uji 10\%).

\begin{tabular}{|c|c|c|c|c|c|}
\hline $\begin{array}{c}\text { Varia } \\
\text { bel }\end{array}$ & $\mathbf{X}_{2}$ & $\mathbf{X}_{3}$ & $\mathbf{X}_{4}$ & $\mathbf{X}_{5}$ & $\mathbf{X}_{8}$ \\
\hline $\mathbf{X}_{1}$ & $\begin{array}{c}\mathbf{r}_{\mathbf{1 1 \times 2} 2}=0 . \\
585\end{array}$ & $\begin{array}{c}\mathbf{r}_{\mathbf{x 1 x} 3}=\mathbf{0} . \\
\mathbf{5 9 7}\end{array}$ & $\begin{array}{c}\mathbf{r}_{\mathrm{xlx4}}=0 . \\
508\end{array}$ & $\begin{array}{c}\mathbf{r}_{\mathbf{x} 1 x 5}=0 \\
652\end{array}$ & $\begin{array}{c}\mathbf{r}_{\mathrm{x1x}}=0 . \\
684\end{array}$ \\
\hline$X_{2}$ & & $\begin{array}{r}\mathbf{r}_{\mathrm{x} 2 \times 3}=0 . \\
\mathbf{7 0 0}\end{array}$ & $\begin{array}{c}r_{\mathrm{x} 2 \times 4}=0 \\
711\end{array}$ & $\begin{array}{c}\mathbf{r}_{\mathrm{x} 2 \times 5}=0 . \\
\mathbf{7 7 3}\end{array}$ & $\begin{array}{c}\mathbf{r}_{\mathrm{x} 2 \times 8}=0 \\
760\end{array}$ \\
\hline $\mathbf{X}_{3}$ & & & $\begin{array}{c}\mathbf{r}_{\mathrm{x} 3 \mathrm{x} 4}=0 . \\
612\end{array}$ & $\begin{array}{c}\mathbf{r}_{\mathbf{x} 3 \times 5}=0 \\
767\end{array}$ & $\begin{array}{c}\mathbf{r}_{\mathrm{x} 3 \mathrm{x} 8}=0 . \\
756\end{array}$ \\
\hline $\mathbf{X}_{4}$ & & & & $\begin{array}{c}\mathbf{r}_{\mathrm{x} 4 \mathrm{x} 5}=0 . \\
609\end{array}$ & $\begin{array}{c}\mathbf{r}_{\mathrm{x} 4 \mathrm{x} 8}=0 . \\
685\end{array}$ \\
\hline$X_{5}$ & & & & & $\begin{array}{c}\mathbf{r}_{\mathrm{x} 5 \mathrm{x} 8}=\mathbf{0} \\
814\end{array}$ \\
\hline
\end{tabular}

Sumber : Output SPSS,

Ukuran Pengaruh Variabel Bebas Terhadap Variabel Tak Bebas

Berdasarkan taksiran koefisien jalur dan koefisien korelasional antar variable, sebagaimana dinyatakan dalam bagian sebelumnya (yang secara lengkap digambarkan dalam gambar 4), maka masing-masing ukuran pengaruh variabel bebas yang signifikans terhadap variabel terikat $\mathrm{Y}$, adalah sebagai berikut :

a. Pengaruh faktor Mengembangkan visi bersama terhadap Efektivitas Kerja Pegawai, sebesar 49,23 persen.

b. Pengaruh faktor Mendidik SDM terhadap Efektivitas Kerja Pegawai, sebesar 59,07 persen, yang sifatnya negatif.

c. Pengaruh faktor Menyingkirkan rintangan-rintangan terhadap Efektivitas Kerja Pegawai, sebesar 14,44 persen.

d. Pengaruh faktor Mengungkapkan sikap terhadap Efektivitas Kerja Pegawai, sebesar 23,40 persen.

e. Pengaruh faktor Menyemangati kerja masalah terhadap Efektivitas Kerja Pegawai, sebesar 34,34 persen

f. Pengaruh faktor Mengharapkan solusi masalah terhadap Efektivitas Kerja Pegawai,, sebesar 29,30 persen.

g. Sehingga variabel efektivitas kerja dapat dijelaskan dari faktor-faktor yang berkaitan dengan pemberdayaan sumber daya manusia sebesar 91,64 persen, dan terdapat faktor lain yang tidak terlibat dalam penelitian ini termasuk kesalahan (error) yang terjadi dalam penelitian yakni sebesar 8,36 persen

\section{KESIMPULAN DAN SARAN}

Berdasarkan hasil penelitian dan pembahasan, berdasarkan hasil pengumpulan data primer dan sekunder, baik dari studi kepustakaan, observasi, wawancara dan angket kepada para pegawai dan melalui pembuktian dengan analisis jalur (path analysis), analisis kuantitatif dan dideskripsikan secara kualitatif, terdapat pengaruh antara Pemberdayaan terhadap efektivitas kerja pegawai di PT Pos Indonesia (persero).

Pengaruh secara parsial dapat disimpulkan sebagai berikut :

1. Mengembangkan visi bersama (X1) terhadap efektivitas kerja memiliki besaran nilai yang positif dan signifikan, artinya bahwa besaran nilai tersebut dimaknai sebagai besaran nilai yang berpengaruh terhadap efektivitas kerja. 
2. Mendidik pegawai (X2) terhadap efektivitas kerja memiliki besaran yang negatif dan signifikan, hal ini membuktikan bahwa besaran nilai tersebut berpengaruh negatif terhadap efektivitas kerja. Hal ini menunjukkan bahwa kegiatan mendidik belum memberikan pengaruh yang signifikan terhadap efektivitas kerja. Pendidikan dan Pelatihan yang diselenggarakan belum memberikan kesempatan secara menyeluruh kepada pegawai dari manajemen puncak hingga pegawai terendah, sehingga peningkatan kemampuan manajerial dan profesional belum dimiliki secara optimal.

3. Menyingkirkan rintangan-rintangan (X3) terhadap efektivitas kerja memiliki besaran nilai positif dan signifikan. Hal ini membuktikan kegiatan menyingkirkan rintangan dengan menghapuskan hambatan-hambatan yang memperlambat pemberian pelayanan kepada masyarakat telah mampu mendorong efektivitas kerja. Pada dasarnya, peraturan, sistem dan prosedur yang sifatnya mendasar perlu tetap ada dalam suatu organisasi, namun pemberdayaan dengan mengurangi sistem, prosedur dan peraturan yang menghambat percepatan pemberian pelayanan telah mampu meningkatkan efektivitas kerja di PT Pos (Indonesia)

4. Mengungkapkan keinginan (X4) terhadap efektivitas kerja memiliki besaran nilai yang positif dan signifikan. Kegiatan mengungkapka keinginan (express) dilakukan dengan mrnjelaskan tujuan organisasi sehingga dipahami sepenuhnya oleh pegawai, mengungkapkan pujian dan penghargaan atas keberhasilan pegawai, mengungkapkan tindakan koreksi terhadap kesalahan pegawai dan memberikan kesempatan mengungkapkan masalah-masalah yang ditemukan ketika bekerja telah berpengaruh terhadap efektivitas kerja.

5. Memberi semangat (X5) terhadap efektivitas kerja memiliki besaran nilai yang positif dan signifikan. Atasan myang senantiasa memberi semangat kepada bawahan membuat pegawai bekerja lebih giat, berkualitas, proaktif, inovatif dan kreatif. Hal ini memberikan kontribusi positif bagi efektivitas kerja.

6. Memberi Perlengkapan (X6) terhadap efektivitas kerja memiliki besaran nilai yang tidak signifikan, hal ini membuktikan bahwa pegawai merasa sarana dan prasarana baik yang menyangkut sistem dan prosedur kerja di PT Pos Indonesia belum dikelola secara optimal, sehingga kurang membantu pegawai dalam mewujudkan efektivitas kerja.

7. Melakukan penilaian (X7) terhadap efektivitas kerja memiliki besaran nilai yang tidak signifikan, hal ini menunjukkan penilaian hasil kerja pegawai belum dilakukan dengan optimal, padahal dengan evaluasi dapat dengan segera diketahui apakah target yang ditentukan - baik yang menyangkut kualitas, kuantitas maupun kemampuan - telah tercapai sepenuhnya atau belum, sehingga pimpinan melakukan perubahanperubahan strategi agar target yang telah ditentukan tercapai di kemudian hari.

8. Mengharapkan keberhasilan (X8) terhadap efektivitas kerja memiliki besaran nilai yang positif dan signifikan. Kegiatan mengharapkan (expect) keberhasilan dan permasalahan dilakukan untuk mengantisipasi kemungkinan munculnya permasalahan-permasalah yang dihadapi dalam memberikan pelayanan, sehingga penanggulangan setiap permsalahan dapat dilakukan secara dini.
9. Variabel Pemberdayaan melalui dimensi-dimensi Mengembangkan Visi Bersama, mendidik pegawai, menyingkirkan rintangan-rintangan, mengungkapkan keinginan, memberi semangat dan mengharapkan keberhasilan merupakan konsep pemberdayaan yang signifikan dan cukup potensial untuk diterapkan di PT Pos Indonesia (persero) guna terwujudnya efektivitas kerja.

Saran :

1. Organisasi hendaknya berusaha meniadakan segala rintangan-rintangan yang menghambat kelancaran pekerjaan, termasuk mengenai peraturan-peraturan yang sifatnya prosedural yang menghambat pelayanan kepada masyarakat.

2. Pengembangan kualitas sumber daya manusia melalui program peningkatan pengetahuan dan keterampilan pegawai hendaknya menjadi perhatian utama dan dilaksanakan secara aktif, konsisten dan menyeluruh. Secara khusus perlu digarisbawahi pentingnya memberi kesempatan kepada pegawai yang diniali memiliki kemampuan dan prestasi untuk dapat melanjutkan ke jenjang yang lebih tinggi, sehingga pegawai menjadi sumber daya yang berdaya.

3. Hendaknya dukungan sarana dan prasarana yang sesuai dengan kebutuhan kerja dan dinamika organisasi dipersiapkan sesuai dengan target yang telah ditentukan.

4. Penilaian terhadap hasil kerja (evaluasi) perlu dilakukan dengan optimal sehingga dengan evaluasi dapat dengan segera diketahui apakah target yang telah ditentukan telah tercapai sepenuhnya atau belum.

\section{DAFTAR PUSTAKA}

Atmosudirdjo, Prajudi. 1982. Administrasi dan Manajement Umum, Jakarta, Ghalia Indonesia

Clutterbuck, David and Susan Kernaghan. 2003. The Art of HRD, The Power of Empowerment (Release the Hidden Talents of Your Employees), Daya Pemberdayaan : Menggali dan Meningkatkan Potensi Karyawan Anda, Terjemahan : Bern Hidayat, Jakarta : Gramedia

Daft, Richard L. 1998. Organization Theory and Design, Sixth Edition, South Western College Publishing

DeVrye, Catherine. 1994. Good Service is Good Business : 7 Simple Strategies for Success, Australia : Prentice Hall

Jones, Gareth R. 2991, Organizational Theory : Text and Cases, Third Edition, Prentice Hall Internationa, Inc

Kasim, Azhar. 1993. Pengukuran Efektivitas dalam Organisasi, Jakarta : Lembaga Penerbit Fakultas Ekonomi Universitas Indonesia.

Lashley, Conrad. 1999. Employee Empowerment in Service : a Framework for Analysis, Personnel Review, Vol 28 no.3, pp. 169-191.

Lashley, Conrad. 2000. Empowerment through Involvement : a case study of TGI Fridays restaurants, Personnel Review, Vol 29 no.6 pp 791-815

Meijia, Gomez Louis R Davis B Balkin, and Robert L Cardy, 1995. Managing Human Resources, New Jersey: Prentice Hall, Englewood Cliffs

Osborne, David and Peter Plastrik, 1997. Banishing Bureaucracy, The Five Strategies for Reinventing Government, New York: Addison-Wesley

Stewart, Aileen Mitchell, 2006. Terjemahan Agus M Hardjana, Empowering People-Pemberdayaan Sumber Daya Manusia, Yogyakarta : Kanisius. 
Soetjipto, Budi W. 2003. Paradigma Baru Manajemen Sumber Daya manusia, Jogjakarta: Penerbit Amara Books.

Wahibur Rokhman, Jr. 2002. Paradigma Baru Manajemen Sumber Daya Manusia : Pemberdayaan dan Komitmen : Upaya Mencapai Kesuksesan Organisasi dalam Menghadapi Persaingan Global, Jogjakarta : Amara Books

Zeithaml, Valare A and Mary Jo Bitner. 2003. Service Marketing : Integrating Customer Focus Across the Firm, $2^{\text {nd }}$ Edition, McGraw-Hill Irwin

PENGARUH PEMBERDAYAAN PEGAWAI TERHADAP EFEKTIVITAS KERJA PADA KANTOR PUSAT PT POS INDONESIA (PERSERO)

Jurnal Bisnis Wirausaha ISSN 1693-234X Volume 7 No.1 Agustus 2012 